\title{
Energy and exergy analysis of an ethanol fueled solid oxide fuel cell power plant.
}

\author{
Yannay Casas ${ }^{a}$, Luis E. Arteaga ${ }^{a}$, Mayra Morales $^{a}$, Elena Rosa ${ }^{b}$, Luis M. Peralta $^{a}$ and Jo \\ Dewulf. \\ ${ }^{a}$ Chemical Engineering Department. Central University of Las Villas. Road to Camajuaní Km 5.5. Santa \\ Clara, c/p 54830, Villa Clara, Cuba. \\ ${ }^{b}$ Applied Chemistry Center, Central University of Las Villas. Road to Camajuaní Km 5.5. Santa Clara, c/p \\ 54830, Villa Clara, Cuba. \\ ${ }^{c}$ Research Group ENVOC, Ghent University, Coupure Links 653, 9000 Ghent, Belgium \\ Telf: (53) (422)-81164 Fax: (53) (422)-81608
}

\begin{abstract}
A solid oxide fuel cell (SOFC) system integrated with an ethanol steam reforming stage is evaluated considering the first and second laws of thermodynamics. The irreversibility losses distribution and the plant energy and exergy efficiencies are studied under different process conditions $(823<\mathrm{T}<973 \mathrm{~K})$ and water to ethanol molar ratios $\left(5<R_{A E}<6.5\right)$. The post combustion of the cell off gases for the heat recovery is also taken into account to maintain the system operation within the auto-sustainability boundaries. An increase of efficiency and irreversibility at the stack is reported when the reactants ratio is increased. The higher losses are placed at the steam reformer $(280 \mathrm{~kW}-350 \mathrm{~kW})$ and the cell $(400 \mathrm{~kW}-$ $590 \mathrm{~kW}$ ) due to the combination of the chemical composition and stream conditions on chemical and physical components of the exergy.
\end{abstract}

Key Words: Exergy Efficiency, Fuel cell, Irreversibility, Steam reforming.

\section{Introduction}

Fuel cells are considered to be the propulsion system of the near future, since they can produce electricity without polluting the environment, and possess the necessary specific power, power density and durability to replace conventional internal combustion engines from their current applications [1]. In recent years, the solid oxide fuel cell (SOFC) running on pure hydrogen or crude gases has drawn great attention, due to its high efficiency and degree of integration even with turbine cycles [2-4]. SOFCs support internal conversion of light hydrocarbons, alcohols and carbon monoxide without using noble metals as electrodes $[1,2,5]$.

A traditional method to study a power generation system is the energetic analysis applying the first law of thermodynamics; it has been widely used to asses the solid oxide fuel cells. In that paper the effect of the steam reforming kinetic pattern was taken into account and the pinch methodology was applied to minimize the use of utilities. However, it is clear that instead, an exergetic analysis with exergy as the measure of the quality (useful part, transformable to work) of energy can be used to specify design optima which are different from those resulting from the energy conservation law [7].

In this sense Douvartzides et al. [9] developed an energy-exergy analysis in order to optimize the operational conditions of a SOFC power plant, considering only the hydrogen oxidation within the fuel cell, and rejecting the effect of the cell losses, insitu methane reforming and carbon monoxide conversion. Moreover, Douvartzides et al. [8-9] did not take into account the effect of the kinetic pattern of the ethanol steam reforming (ESR) on syngas composition and instead they use the extent of the reaction $(\varepsilon)$. The optimal condition was reached for a SOFC fuel utilization factor of $79.85 \%$, an ethanol conversion of $100 \%$, water to ethanol ratio $3: 1$ and no energy integration was developed.

The exergy analysis of an integrated internal methane reforming - solid oxide fuel cell - gas turbine (IRSOFC-GT) power generation system was performed by Pegah [10]. 
The in-situ partial oxidation of methane and the electrochemical oxidation of hydrogen at the cell anode were taken as main reactions. Fuel cell off gas was used to feed a turbine fulfilling in this way the power requirements for fuel compression. The thermodynamic losses in each unit were calculated and no energy integration strategy was taken into consideration.

The use of renewable fuels coupled to SOFCs have been also reported by Panopoulus et al. [1112] and Fryda et al. [13] which studied the exergy efficiency of a biomass steam gasification reactor integrated with a high temperature SOFC in a combined heat and power scheme.

In the present paper, the first and second laws of thermodynamics are combined to obtain a system configuration and optimal operational conditions for an external catalytic ethanol steam reformer coupled to a solid oxide fuel cell system. The system combines the renewable character of ethanol with the technical advantages of fuel cells to design a near zero emission system with a high degree of efficiency. On the other hand, a detailed thermodynamic model for the evaluation of the SOFC is provided and a kinetic model is used to asses the conversion of methane within cell anode. The distribution of irreversibility on each device and the whole process are reported joined to the exergy and energy efficiencies. The study starts with an integrated process flow diagram as base case [14] and all the analysis are developed taken into account the effect of the heat exchanger network (HEN) design throw pinch methodology.

The mathematical processing of the models is carried out using the Aspen - Hysys ${ }^{\circledR}$ general purpose modeling-environment.

\section{Description of the system}

The ethanol steam reformer - solid oxide fuel cell systems are depicted in Fig. 1. The initial fluxes of water and ethanol are pumped into the Mixer where an isothermal mixing takes place at atmospheric conditions (298 K and 1atm). After that, the liquid mixture is vaporized and preheated on devices HEX-1 and HEX-2 prior to the Reactor inlet. The endothermic steam reforming of the ethanol $\Delta \mathrm{H}=+173.5 \mathrm{~kJ} / \mathrm{mol})$ is studied considering a packed bed reactor charged with a
$\mathrm{Ni} / \mathrm{Al}$ hydrotalcite catalyst [15-16] and among the various reaction patterns reported previously [14,1617] the Lagmuir-Hishelwood kinetic model reported in Arteaga et al. [6,14] is used to describe a six step reaction scheme including the coke deposition on catalyst surface

The mixture leaving the Reactor is then fed into a solid oxide fuel cell module where an air flux $\left(21 \% \mathrm{O}_{2}\right.$, $79 \% \mathrm{~N}_{2}$ ) is used as oxidant which is previously compressed and heated in a Compressor, HEX-3 and HEX-4. The SOFC model is used to study the process and to design various scenarios considering variations of the reformer operational parameters.

Since the $\lambda_{\text {sofC }}$ ratio of the syngas fed into the anode is higher than two, no carbon deposition problems are supposed to occur on the anode of the SOFC and the in-situ methane reforming; this is studied using a kinetic reactor model which considers the power law pattern with a negative reaction order for water [23]. Moreover, the shift conversion of the carbon monoxide is simulated using a Gibbs reactor model (equilibrium), in this way the offgas composition is calculated rigorously and the energy recuperation in the post-combustor agrees with the real picture of the problem. The fuel utilization factor is defined by (Eq. 1). The heat balance in the cell considers the heat consumed in the methane reforming and the heat produced by the electrochemical reaction and shift conversion.

$$
\mathrm{U}_{\mathrm{f}}=\frac{\left(\mathrm{f}^{\mathrm{in}} \mathrm{H}_{2}+4 \cdot \mathrm{X}_{\mathrm{CH} 4} \cdot \mathrm{f}^{\mathrm{in}} \mathrm{CH} 4+\mathrm{X}_{\mathrm{CO}} \cdot \mathrm{f}^{\mathrm{in}} \mathrm{CO}-\mathrm{f}^{\text {out }}{ }_{\mathrm{H} 2}\right)}{\left(\mathrm{f}^{\mathrm{in}} \mathrm{H} 2+4 \cdot \mathrm{X}_{\mathrm{CH} 4} \cdot \mathrm{f}^{\mathrm{in}} \mathrm{CH} 4+\mathrm{X}_{\mathrm{CO}} \cdot \mathrm{f}^{\mathrm{in}} \mathrm{CO}\right)}
$$

The SOFC exhaust containing $\mathrm{H}_{2}, \mathrm{CH}_{4}, \mathrm{O}_{2}, \mathrm{~N}_{2}$, CO, $\mathrm{H}_{2} \mathrm{O}$, and $\mathrm{CO}_{2}$ is cooled (to avoid $\mathrm{NO}_{\mathrm{x}}$ formation) and burned downstream in the post-combustion system. The post-combustion unit is modeled as an adiabatic conversion reactor (ConvReact) and the depleted heat is used to balance the energy requirements in the process. 


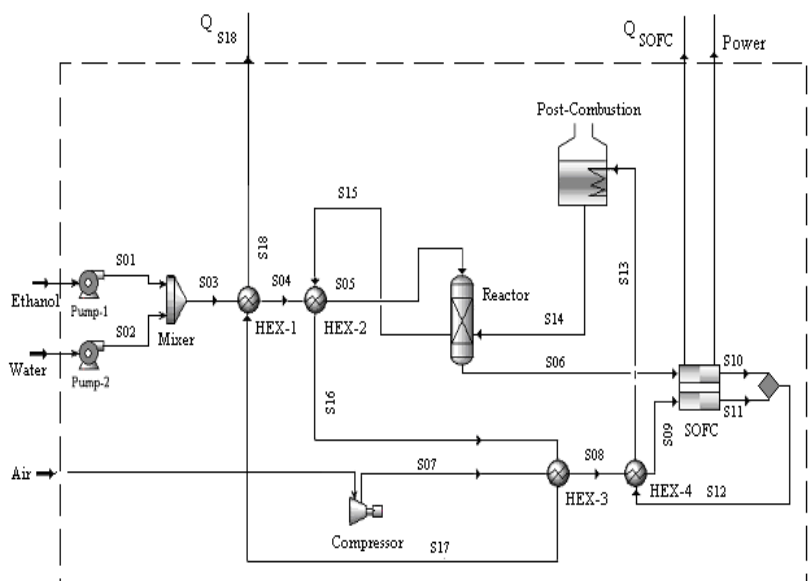

Fig 1. Process flow diagram (PFD).

\section{Second Law Analysis}

physical and chemical; more precisely, the physical exergy expresses the useful work that a substance can produce when brought reversibly from its state to the "restricted dead state" and it can be written as:

$$
e_{i}^{p h}=\left(H-H_{0}\right)_{i}-T_{0}\left(S-S_{0}\right)_{i}
$$

Chemical exergy is obtained when the components of the energy carrier are first converted to reference compounds and then diffuse into the environment, which is in reference (dead) state. For a gaseous stream flow, the molar chemical exergy $\left(e_{i}^{\text {ch }}\right)$ of all species is given by the (2) Fryda et al. [13]:

$$
\mathrm{e}_{\mathrm{i}}^{\mathrm{ch}}=\sum \mathrm{x}_{\mathrm{i}} \cdot \mathrm{e}_{\mathrm{i}}^{\mathrm{o}}+\mathrm{RT}_{\mathrm{o}} \sum \mathrm{x}_{\mathrm{i}} \cdot \ln \left(\mathrm{x}_{\mathrm{i}}\right)
$$

No deviations between real environmental and reference conditions are considered. The standard chemical exergies of all components of each stream represented in the PFD (Fig. 1) are showed in the Table 1.
Exergy analysis is a thermodynamic method of using the conservation of mass and energy principles together with the Second Law of Thermodynamics for the design and analysis of thermal systems. The purpose of an exergy analysis is generally to identify the location, the source, and magnitude of true thermodynamic inefficiencies in a given process. Exergy is the maximum work that can be produced when a heat or material stream is brought to equilibrium in relation to a reference environment. In this study a temperature of $\mathrm{T}_{0}=298.15 \mathrm{~K}$, pressure $\mathrm{P}$ $=1.013$ bar and environment composition of $75.67 \%$ $\mathrm{N}_{2}, 20.35 \% \mathrm{O}_{2}, 0.03 \% \mathrm{CO}_{2}, 3.03 \% \mathrm{H}_{2} \mathrm{O}$ and $0.92 \%$ Ar are assumed as reference [18].

In the present article the exergy of each material stream is expressed as the sum of two components,

Table1.Standards Chemical Exergy (Stds.Chem.Exergy) of individual species. [26]

\begin{tabular}{lll}
\hline Species & Formula & $\begin{array}{l}\text { Stds. } \\
\text { Exergy }\end{array}$ \\
\hline Nitrogen & $\mathrm{N}_{2}$ & 720 \\
Oxygen & $\mathrm{O}_{2}$ & 3970 \\
Water & $\mathrm{H}_{2} \mathrm{O}_{\mathrm{g}}$ & $1.171 .10^{4}$ \\
Water & $\mathrm{H}_{2} \mathrm{O}_{1}$ & 3120 \\
Carbon & $\mathrm{CO}_{2}$ & $2.014 .10^{4}$ \\
Dioxide & & \\
Carbon & $\mathrm{CO}$ & $2.754 .10^{5}$ \\
Monoxide & & \\
Argon & $\mathrm{Ar}$ & $1.169 .10^{4}$ \\
Ethanol & $\mathrm{C}_{2} \mathrm{H}_{5} \mathrm{OH}$ & $1.371 .10^{6}$ \\
& $\mathrm{~g}$ & \\
Ethanol & $\mathrm{C}_{2} \mathrm{H}_{5} \mathrm{OH}$ & $1.365 .10^{6}$ \\
Methane & $\mathrm{CH}_{4}$ & $8.365 .10^{5}$ \\
Hydrogen & $\mathrm{H}_{2}$ & $2.385 .10^{5}$ \\
Carbon & $\mathrm{C}$ & $4.108 .10^{5}$ \\
\hline
\end{tabular}

Note: All the exergy values are presented in $\mathrm{kJ}$. $\mathrm{Kmol}^{-1}$.

An exergy balance for a control volume at steady state is formulated to calculate the exergy destruction $\left(E_{\text {Dest }}\right)$ of the system at different operational conditions. In the present work all the inlet and outlet streams are considered to determine the irreversibility distribution, which include the sum of matter, energy and power. The mixer, heat exchangers (HEX-1 to HEX-6), 
ethanol steam reforming reactor, the SOFC module, the post-combustion unit and the auxiliary equipments (pumps and compressor) are included into the limits of the system (Dashed lines area in Fig. 1). The process global exergy balance, by ignoring the changes in kinetic and potential exergies, is expressed as:

$$
\begin{aligned}
& \mathrm{E}_{\text {irrev }}=\left(\sum \mathrm{f}_{\mathrm{i}} \cdot \mathrm{e}_{\mathrm{i}}\right)_{\text {inlet }}-\left(\sum \mathrm{f}_{\mathrm{i}} \cdot \mathrm{e}_{\mathrm{i}}\right)_{\text {outlet }} \\
& +\sum_{\mathrm{j}}\left(1-\frac{\mathrm{T}_{\mathrm{O}}}{\mathrm{T}_{\mathrm{j}}}\right) \mathrm{Q}_{\mathrm{j}}-\mathrm{W}
\end{aligned}
$$

Where $E_{\text {irrev }}=T o * S_{\text {gen }}$ (the Gouy -Stodola theorem) represents the rate of exergy destruction into the device due to irreversibilities, $e_{i}$ is the total exergy of each chemical species $i$, which is the sum of the physical and chemical exergies.

\subsection{Definition of the irreversibilities}

Irreversibility at each stage of the process is calculated based on the approaches described previously. The equations for the evaluation of this parameter are present below.

\subsubsection{Steam reforming reactor}

Exergy destruction of the ESR can be expressed by the following equation.

$$
\mathrm{E}_{\mathrm{ESR}}=\left(\begin{array}{l}
\mathrm{f}_{\mathrm{S} 05} \cdot \mathrm{e}_{\mathrm{S} 05}+\mathrm{f}_{\mathrm{S} 14} \cdot \mathrm{e}_{\mathrm{S} 14} \\
-\mathrm{f}_{\mathrm{S} 06} \cdot \mathrm{e}_{\mathrm{S} 06}-\mathrm{f}_{\mathrm{S} 15} \cdot \mathrm{e}_{\mathrm{S} 15}
\end{array}\right)
$$

\subsubsection{Heat Exchanger equipment}

The exergy balances in all heat exchanger devices can be expressed as follows:

$$
\begin{aligned}
& \mathrm{E}_{\text {HEX }}=\left(1-\frac{\mathrm{T}_{\mathrm{o}}}{\mathrm{T}_{\mathrm{j}}}\right) \mathrm{Q}_{\mathrm{j}}+\mathrm{f}\left[\left(\mathrm{e}_{\mathrm{k}}^{\mathrm{ph}}\right)_{\text {inlet }}-\left(\mathrm{e}_{\mathrm{k}}^{\mathrm{ph}}\right)_{\text {outlet }}\right] \text { hot } \\
& +\mathrm{f}\left[\left(\mathrm{e}_{\mathrm{k}}^{\mathrm{ph}}\right)_{\text {inlet }}-\left(\mathrm{e}_{\mathrm{k}}^{\mathrm{ph}}\right)_{\text {outlet }}\right]_{\text {cold }}
\end{aligned}
$$

Where $\mathrm{j}$ is the heat exchangers and $\mathrm{k}$ represent each stream of process (inlet and outlet).

The previous equation is not affected by chemical exergy due to the chemical compositions of the hot and cold inlet streams are constants in the heat exchange equipment.

\subsubsection{Solid Oxide Fuel Cell}

The chemical transformations into the fuel cell cathode and anode, the dissipated heat to the environment and the power delivered by the electrochemical reaction are considered into the irreversibilities. Then the exergy destruction in the SOFC is calculated as below:

$$
\begin{aligned}
& \mathrm{E}_{\text {SOFC }}=-\left(1-\frac{\mathrm{T}_{\mathrm{O}}}{\mathrm{T}_{\mathrm{SOFC}}}\right) \mathrm{Q}_{\text {SOFC }}-\mathrm{P}_{\text {SOFC }} \\
& +\Sigma\left[\left(\mathrm{f}_{\mathrm{S} 09} \cdot \mathrm{e}_{\mathrm{S} 09}-\mathrm{f}_{\mathrm{S} 11} \cdot \mathrm{e}_{\mathrm{S} 11}\right)\right]_{\mathrm{C}} \text { athode } \\
& +\Sigma\left[\left(\mathrm{f}_{\mathrm{S} 06} \cdot \mathrm{e}_{\mathrm{S} 06}-\mathrm{f}_{\mathrm{S} 10} \cdot \mathrm{e}_{\mathrm{S} 10}\right)\right]_{\text {anode }}
\end{aligned}
$$

\subsubsection{Compressor}

The expressions to determine the compressor irreversibilities are reported by Pegah [10]. It takes into account the compression ratios, polytropic efficiencies and fluid conditions.

$$
\mathrm{E}_{\mathrm{C}}=\mathrm{f}_{\text {air }} \cdot \mathrm{R} \cdot \mathrm{T}_{\mathrm{o}}\left(\frac{1-\eta_{\mathrm{p}, \mathrm{C}}}{\eta_{\mathrm{p}, \mathrm{C}}}\right) \cdot \ln (\mathrm{CPR})
$$

\subsubsection{Post-Combustion unit}

In the after burner the irreversibility is defined considering the chemical and physical components, the losses by heat transfer are zero because the combustor operates adiabatically:

$$
\begin{aligned}
& { }_{\mathrm{PC}}=\left(\mathrm{f}_{\mathrm{S} 13} \cdot \mathrm{e}_{\mathrm{S} 13}^{\mathrm{ch}}-\mathrm{f}_{\mathrm{S} 14} \cdot \mathrm{e}_{\mathrm{S} 14}^{\mathrm{ch}}\right) \\
& +\left[\begin{array}{l}
\left.\mathrm{f}_{\mathrm{S} 13} \cdot \mathrm{H}_{\mathrm{S} 13}-\mathrm{f}_{\mathrm{S} 14} \cdot \mathrm{H}_{\mathrm{S} 14}\right) \\
-\mathrm{T}_{0}\left(\mathrm{f}_{\mathrm{S} 13} \cdot \mathrm{S}_{\mathrm{S} 13}-\mathrm{f}_{\mathrm{S} 14} \cdot \mathrm{S}_{\mathrm{S} 14}\right)
\end{array}\right]
\end{aligned}
$$

\section{System energy and exergy efficiencies}

Energy efficiency of the whole system (Eq.10) is defined by the ratio between the delivered power and the amount of energy contained in the ethanol molecular structure it is referred to the LHV.

$$
\eta_{\text {energy }}=\frac{\sum_{\mathrm{j}} \mathrm{W}_{\mathrm{j}}}{\left(\mathrm{f}^{\mathrm{in}} \cdot \mathrm{LHV}\right)_{\text {ethanol }}}
$$

Where $\sum_{j} W_{j}$ is the global power generated by the system (work produced - work consumption). 
On the other hand, exergy efficiency (Eq.11) is referred to the exergetic potential of the primary fuel (standard exergy of ethanol).

$$
\eta_{\text {exergy }}=\frac{\sum_{j} W_{j}}{\left(f^{\text {in }} \cdot e^{\mathrm{o}}\right)_{\text {ethanol }}}
$$

\section{Results and discussion}

\subsection{Exergy analysis considering operation parameters}

An exergy study has been developed in order to simulate the power plant using the Solid Oxide fuel cell technology represented in the Fig. 1. This simulation program is able to calculate the flow rate, temperature, pressure, energy and the exergy content in every stream of inlet and outlet as well as the exergy destruction by irreversibilities of each stage involved in the plant.

The results of the exergy analysis applied to the base case are shown in the Table 2 . The conditions selected were $\mathrm{T}_{\mathrm{ESR}}=\mathrm{T}_{\mathrm{SOFC}}=923 \mathrm{~K}, \mathrm{R}_{\mathrm{AE}}=6.0, \mathrm{U}_{\mathrm{f}}$ $=80 \%, \mathrm{~V}_{\text {cell }}=0.64 \mathrm{~V}$, compressor polytrophic efficiency $\eta_{\mathrm{p}, \mathrm{c}}=90 \%$ and $\lambda_{\text {SOFC }}>2$. Considering the standard chemical potential of ethanol as the inlet flow availability, the irreversibilities represent approximately $66 \%$ of the flow availability, so the exergy efficiency takes a value of $34 \%$.

Table 2. Base case simulation results.

\begin{tabular}{|c|c|c|c|c|c|}
\hline 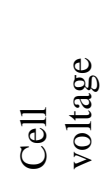 & 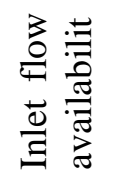 & 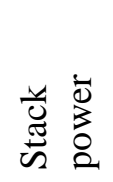 & 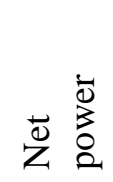 & 总. & 完 \\
\hline $0.6 \mathrm{~V}$ & $\begin{array}{l}1480 \\
\mathrm{~kW}\end{array}$ & $\begin{array}{l}569 \\
\mathrm{~kW}\end{array}$ & $\begin{array}{l}502 \\
\mathrm{~kW}\end{array}$ & $\begin{array}{l}37.6 \\
\%\end{array}$ & $\begin{array}{l}33.9 \\
\%\end{array}$ \\
\hline
\end{tabular}

The effect of the reforming temperature and reactants molar ratio on exergetics efficiency and losses are presented in the Fig. 2 and Fig. 3 respectively.

The fuel cell power and the ethanol flow have a notable influence on the exergy efficiency according to the definition written previously. On the other hand, the cell power is directly proportional to the hydrogen obtained in the reformer. Because of this; the higher hydrogen yield allows the increase of the SOFC power as well as the exergy efficiency. According to the explanation above; the exergy efficiencies are favored by higher reformer temperatures and water to ethanol feed ratios. Exergetic efficiencies reach values ranging from $32 \%$ to $35 \%$ approximately in all analyses; the higher efficiencies are obtained at $973 \mathrm{~K}$ and $\mathrm{R}_{\mathrm{AE}}$ of 6.5 .

From an irreversibility point of view, the system studied is not favored by the increase of the reformer operation variables. The lower irreversibility values are obtained at lower temperature and $R_{\mathrm{AE}}$, nevertheless it corresponds to lower exergy efficiency of the process (less than 30\%), and so there should always be a balance between system efficiency and system irreversibility.

Further on, it is important to express that the flow diagram is designed on integration principles allowing an optimal use of the hot streams and keeping the design of the plant to operate autonomously, without any interaction between external sources of heat and power (auto-sustainability).

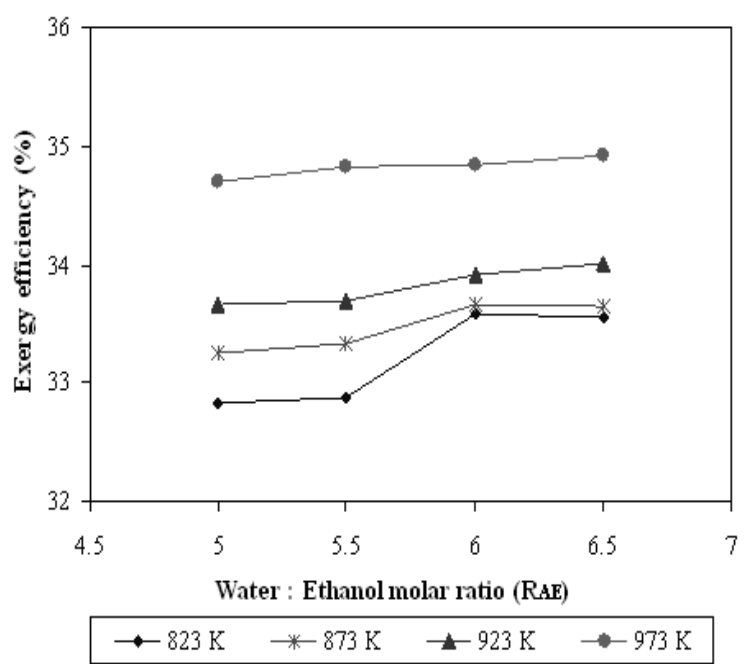

Figure 2. Effect of the reforming temperature and $R_{A E}$ on exergetic efficiency. 


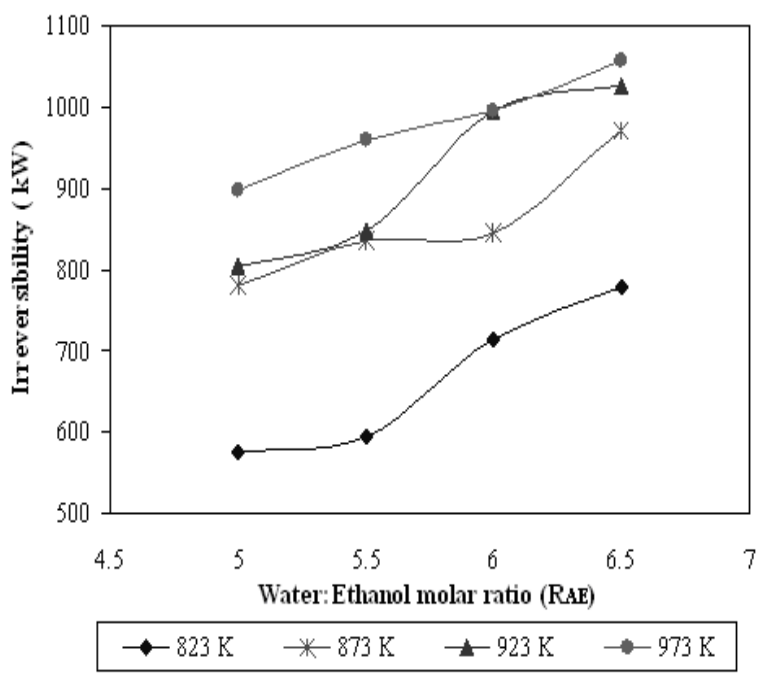

Figure 3. Irreversibilities, varying the reforming temperature and $R_{A E}$.

The irreversibility of the stages involved in the plant at reforming temperature of $923 \mathrm{~K}$ is illustrated in Fig. 4. The total exergy destruction in the system is caused mainly by the SOFC, reformer and post-combustor, which represents more than the $50 \%$ of the inlet flow availability, similar results are reported by Pegah [10]. Changes in the chemical exergies are more relevant than the changes of the physical contributions; this phenomenon is related fundamentally with the chemical reactions extents.

The exergy destruction of the reformer is increased from $276.13 \mathrm{~kW}$ to $336.53 \mathrm{~kW}$ for feed molar ratios of 5 and 6.5 respectively. That change in performance is due to the increase on the demands of heat in the reformer with $\mathrm{R}_{\mathrm{AE}}$, which is caused by the increase of reactions conversion taking place in this stage and the total flow.

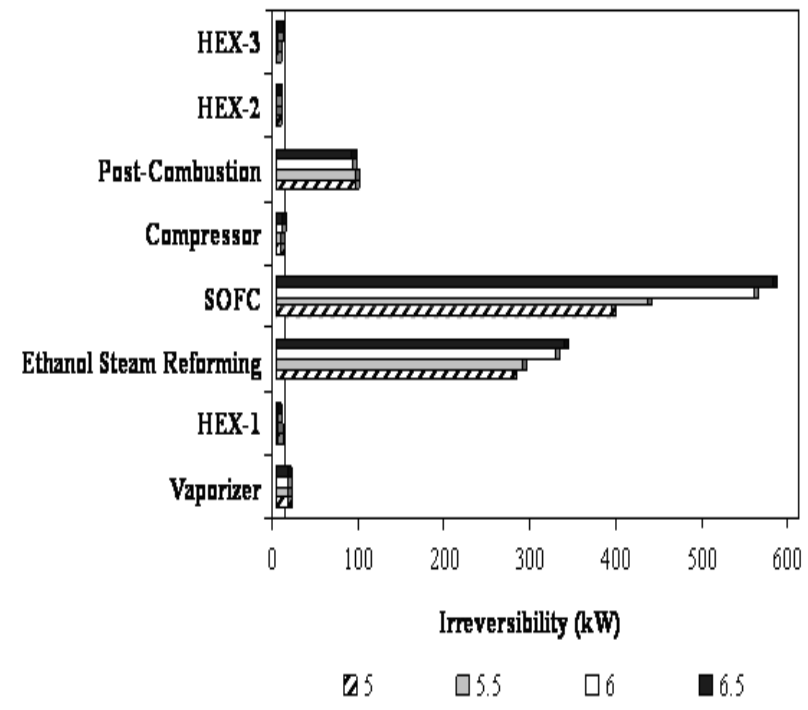

Figure 4. Exergy destruction by irreversibility in cycle stages varying $R_{A E}$.

In order to investigate the performance of the exergetic losses in the fuel cell, we assumed that the heat rejected by the electrochemical reaction is a waste, because of this; the exergy destructions by heat losses are significant, reaching values of $70 \%$ of the exergy destruction of the SOFC for water to ethanol molar ratio of 6.5. The efficient use of wasted heat by the cell in a turbine, heat engines or in a combined cycle can reduce the irreversibilities in this stage and the global system, as well as to improve the exergy and energy efficiencies [19].

The increase of $\mathrm{R}_{\mathrm{AE}}$ produce a higher hydrogen flow to the fuel cell, converting more chemical energy into electricity, which means more current and power produced. Nevertheless at the same condition, the irreversibility is increased in the fuel cell stack due to the increase of the waste heat and dissipative phenomena (overpotential losses).

The exergy destruction in the post-combustor presents a little decrease for different $\mathrm{R}_{\mathrm{AE}}$. Those losses are associated to the irreversibility of the combustion process of $\mathrm{H}_{2}, \mathrm{CO}$ and $\mathrm{CH}_{4}$, the amounts of reactants, the temperature of the combustor and the stoichiometric ratio of the combustion. In this case the amounts of fuels take an important role; especially the energetic content of the inlet stream is reduced with 
the increase of the water to ethanol molar ratio, allowing lower losses by the heat transfer.

\section{Conclusions}

The evaluation presented in this paper allows obtaining a complete idea of the real work delivered by an integrated solid oxide fuel cell and an ethanol steam reforming unit and it relationship with the most relevant operation variables. The effect of water to ethanol ratio and the reforming temperature on the energy and exergy efficiency of the system was also discussed.

The higher exergy efficiencies (35\% at $973 \mathrm{~K}$ and $\mathrm{R}_{\mathrm{AE}}=6.5$ ) also coincide with higher total irreversibility losses $(1050 \mathrm{~kW})$ due to the effect of the change in both the chemical and physical components. It was also demonstrated that a balance should be established by the process engineer considering equilibrium between power production and process efficiencies.

\section{Nomenclature}

CPR compression ratios

$E$ exergy destruction, $\mathrm{kW}$.

$\mathrm{e}_{\mathrm{i}}$ total exergy of each chemical species, $\mathrm{kJ} / \mathrm{kmol}$.

$e^{c h}{ }_{i}$ molar chemical exergy of species, $\mathrm{kJ} / \mathrm{kmol}$.

$\mathrm{e}^{\mathrm{ph}}{ }_{\mathrm{i}}$ molar physical exergy of species, $\mathrm{kJ} / \mathrm{kmol}$.

$F^{\text {in }}{ }_{\text {ethanol }}$ ethanol flow feed to the reactor, $\mathrm{kmol} / \mathrm{s}$.

$H$ molar absolute enthalpy, $\mathrm{kJ} / \mathrm{mol}$.

$H_{o}$ molar enthalpy at reference state, $\mathrm{kJ} / \mathrm{mol}$.

$P_{\text {SOFC }}$ cell power output, $\mathrm{kW}$.

$Q$ heat duty of component, $\mathrm{kW}$.

$R$ universal gas constant, $\mathrm{J} /(\mathrm{K} \mathrm{mol})$.

$R_{A E}$ water/ethanol molar ratio.

$S$ molar absolute entropy, $\mathrm{kJ} /(\mathrm{mol} \mathrm{K})$.

$S_{o}$ molar entropy at reference state, $\mathrm{kJ} /(\mathrm{mol} \mathrm{K})$.

$T$ temperature of component $\mathrm{j}, \mathrm{K}$.

$\mathrm{T}_{0}$ temperature of reference state, $298.15 \mathrm{~K}$.

$x$ mole fraction of species.

\section{Greeks Letters}

$\eta_{\text {exergy }}$ exergy efficiency, \%.

$\eta_{\text {energy }}$ energy efficiency, \%.

\section{Subscripts}

C compressor.
ESR reformer.

HEX heat exchanges.

Hot stream of HEX.

Cold stream of HEX.

PC post-combustion.

SOFC solid oxide fuel cell.

i each chemical species of the stream.

j each component of system (mixer, reformer...fuel cell).

$\mathrm{k}$ streams of process ( inlet and outlet)

S06, S07...S15 streams of the flow diagram

\section{References}

[1]. Hirschenhofer, J.H., et al., 2006, Fuel Cells Handbook, sixth Ed., EG \& G Technical Services, National Energy Technology Laboratory. P.O. Box 880. Morgantown, West Virginia 26507-0880.

[2]. Thorud, B., 2005. Dynamic Modelling and Characterization of a Solid Oxide Fuel Cell Integrated in a Gas Turbine Cycle. Doctoral Thesis. Department of Energy and Process Engineering. Norwegian University of Science and Technology.

[3]. Calise, F., Palomb, A., Vanoli, L., 2006, Design and partial load exergy analysis of hybrid SOFC-GT power plant, Journal of Power Sources, (158), pp. 225 - 244.

[4]. Calise, F., et al., 2006, Simulation and exergy analysis of a hybrid Solid Oxide Fuel Cell (SOFC)-Gas Turbine System, Energy, (31), pp. 3278-3299.

[5]. Ballard., 2007, Case Study - Residential Cogeneration. Groundbreaking Fuel Cell Solution. Ballard Power Systems Inc. 9000 Glenlyon Parkway Burnaby, British Columbia.

[6]. Arteaga-Perez, L.E., et al., 2009, An autosustainable solid oxide fuel cell system fueled by bio-ethanol Process simulation and heat exchanger network synthesis, Chemical Engineering Journal, 150, pp. 242-251.

[7]. Hotz, N., Sen, S.M., Poulikakos, D., 2006, Exergy analysis of a solid oxide fuel cell 
micropowerplant, J. of Power Sources, 158, pp. 333-347.

[8]. Douvartzides, S, Coutelieris, F., Tsiakaras, P., 2004, Exergy analysis of a solid oxide fuel cell power plant fed by either ethanol or methane, Journal of Power Sources, 131, pp. 224-230.

[9]. Douvartzides, S., Coutelieris, F., Tsiakaras, P., 2003, On the systematic optimization of ethanol fed SOFC-based electricity generating systems in terms of energy and exergy, Journal of Power Sources, 131, pp. 224-230.

[10]. Pegah, G.B., 2007, Energy and Exergy analysis of internal reforming solid oxide fuel cell- gas turbine hybrid system, International journal of hydrogen energy, 32, pp. 4591-4599.

[11]. Panopoulos, K.D., et al., 2006, High temperature solid oxide fuel cell integrated with novel allothermal biomass gasification Part II, Exergy analysis, Journal of Power Sources, 159, pp. 586594.

[12]. Panopoulos, K.D., et al., 2006, High temperature solid oxide fuel cell integrated with novel allothermal biomass gasification Part I, Modelling and feasibility study, Journal of Power Sources, 159, pp. 570-585.

[13]. Fryda, L., et al., 2008, Exergetic analysis of solid oxide fuel cell and biomass gasification integration with heat pipe, Energy, 33, pp. 292-299.

[14]. Arteaga, L. E., et al., 2008, Bioethanol steam reforming for ecological syngas and electricity production using a fuel cell SOFC system, Chemical Engineering Journal, 136, pp. 256-266.

[15]. Mas, V., et al., 2008, Ethanol steam reforming using $\mathrm{Ni}(\mathrm{II})-\mathrm{Al}(\mathrm{III})$ layered double hydroxide as catalyst precursor, Chemical Engineering Journal, 138, pp. 602-607.

[16]. Mas, V., et al., 2008, Ni(II)-Al(III) layered double hydroxide as catalyst precursor for ethanol steam reforming: Activation treatments and kinetic studies, Catalysis Today, 133 (135), pp. 319-323.

[17]. Akande, A., et al., 2006, Kinetic modeling of hydrogen production by the catalytic reforming of crude ethanol over a coprecipitated $\mathrm{Ni}-\mathrm{Al}_{2} \mathrm{O}_{3}$, International Journal of Hydrogen Energy, 31, pp. 1707-1715.

[18]. Kotas, T.J., 1995, The exergy method of thermal plant analysis. Florida: Krieger Publishing Company.

[19]. Hernandez, L., Viatcheslav K.V., 2008, Use of bioethanol for sustainable electrical energy production, Int. J of Hydrogen Energy, in press. 